\title{
THE RELEVANCE OF BUSINESS NEGOTIATION IN BUILDING COMPETITIVE ADVANTAGE FOR CROATIAN MICRO ENTERPRISES
}

\author{
Katija Vojvodić ${ }^{*}$ \\ Marija Martinović** \\ Ana Pušić***
}

\begin{abstract}
Although the term small and medium-sized enterprises (SMEs) originally include micro, small and medium enterprises, the majority of literature looks at this sector as a homogeneous group. In general, there is insufficient research on micro-enterprises and previous work has failed to address micro-enterprises in the negotiation context. As a result, the negotiating behavior of micro-entrepreneurs is still poorly understood. Therefore, the aim of this paper is twofold. Firstly, our aim is to examine if the managers of micro-enterprises perceive business negotiations as a source of competitive advantage. Secondly, we aim to identify the underlying predictors of such perception. To this end, the survey was conducted among 132 managers of micro-enterprises in Croatia. The multiple linear regression results reveal that negotiating frequency, negotiation skills development, and willingness to change have a significant and positive influence on managers' perception of business negotiations as a competitive advantage. Finally, the paper adds to the literature by providing insights into the negotiating behavior of micro-entrepreneurs in Croatia.
\end{abstract}

KEYWORDS: business negotiation, micro-enterprises, competitive advantage, negotiating behavior, Croatia

\footnotetext{
* Katija Vojvodić, University of Dubrovnik Department of Economics and Business, Croatia; katija.vojvodic@unidu.hr.

** Marija Martinović, University of Dubrovnik Department of Economics and Business, Croatia; marija.martinovic@unidu.hr.

*** Ana Pušić, University of Dubrovnik Department of Economics and Business, Croatia; apusic@unidu.hr.
} 


\section{INTRODUCTION}

In broad terms, negotiation comprises the exchange of information and engaging in the give-and-take process in order to reach an agreement that satisfies the interests of all parties involved. In their essence, negotiation processes encompass dynamic events in which different dimensions are managed simultaneously. ${ }^{1}$ The process of negotiation often involves a wide range of various activities, such as planning, listening, questioning, understanding, anticipating, explaining, influencing, relationship building, the building of trust, bargaining, problem-solving, making proposals, making concessions, using tactics, etc.

Essentially it can be said that negotiation is a complex interactive process and a highly sophisticated form of communication. The nature of negotiation is about exercising patience, using emotions, threatening, thinking about the next steps and consequences, taking control, managing conflicts, and making decisions. Consequently, the negotiation process has been an intriguing area of research. Thus, the topic of business negotiation has attracted considerable interest within organizational behavior and management science for the past fifty years. ${ }^{2}$

Another definition of negotiation refers to a tool, which can be useful in achieving one's goals. ${ }^{3}$ Apart from being an everyday necessity, the process of negotiation can be regarded as a game of strategy. ${ }^{4}$ Each negotiation process creates unique challenges and consists of a set of sub-processes to suit the needs of the parties involved. Consequently, the need for a flexible and creative problem-solving approach in the negotiation context is often outlined. Furthermore, a negotiation can be interpreted as art..$^{5}$ In that context, successful leadership and management of the negotiation process incorporate multiple positions of power. ${ }^{6}$

As regards Croatian business settings, the studies focusing on the negotiation processes are rather limited. In particular, there is a lack of studies examining

\footnotetext{
1 Age, L. J., Eklinder-Frick, J.: Goal-oriented balancing: happy-happy negotiations beyond win-win situations, Journal of Business \& Industrial Marketing, 32(4) 2017, p. 525-534.

2 Brett J., Thompson L.: Negotiation, Organizational Behavior and Human Decision Processes, 136, 2016, p. 68-79.

3 Spencer, P. J.: Successful Negotiation Skills, West Midlands, 2013, p. 7.

4 Uher, T. E., Loosemore, M.: Essentials of Construction Project Management, Sydney, 2004, p. 302.

5 Gates, S.: The Negotiation Book: Your Definitive Guide to Successful Negotiating, West Sussex, 2016, p. 1.

6 Magee J.: The Managerial Leadership Bible: Learning the Strategic, Organizational, and Tactical Skills Everyone Needs Today, New Jersey, 2015, p. 293.
} 
the negotiation behavior of Croatian managers. So far, previous research has mainly focused on negotiation as a business process that adds value ${ }^{7}$, the role of business negotiation in gaining competitive advantage ${ }^{8}$, skills and negotiating behavior of Croatian business executives ${ }^{9}$, negotiation skills as key competences for entrepreneurship development ${ }^{10}$, business negotiation as a crucial component of sales ${ }^{11}$, the role of negotiation in the corporate banking market ${ }^{12}$, and business negotiations with large retail stores. ${ }^{13}$ However, little is known about the negotiation behavior of Croatian managers in general and managers in micro-enterprises in particular.

The development of micro-enterprises is usually considered in the broader context of small and medium-sized enterprises (SMEs) sector. Nowadays, micro-enterprises play a crucial role in the European economy. In 2016, the majority $(93.0 \%)$ of enterprises in the European Union's non-financial business economy were micro-enterprises. ${ }^{14}$ According to the average number of employees, micro-business entities are natural and legal persons with less than ten persons employed annually. ${ }^{15}$ In 2018, micro-enterprises accounted for the share of $27.2 \%$ in total employment at the level of Croatia, almost equal to that of large enterprises in terms of employment. At the same time, they accounted for the smallest shares in total income and total exports. ${ }^{16}$

7 Tomašević Lišanin, M.: Pregovaranje - poslovni proces koji dodaje vrijednost, Zbornik Ekonomskog fakulteta u Zagrebu, 2(1) 2004, p. 143-158.

8 Križman Pavlović, D., Kalanj, I.: Role of business negotiation in gaining competitive advantage, Economic Research, 21(4) 2008, p. 62-81.

9 Tomašević Lišanin, M., Razum, A., Marić, N.: Skills and negotiation behaviour of Croatian Businessmen, International Journal of Sales, Retailing and Marketing, 4(4) 2015, p. 168178.

10 Šlogar, H., Cigan, V.: Umijeće pregovaranja kao ključna kompetencija u razvoju poduzetništva, Učenje za poduzetništvo, 2(2) 2012, p. 259-265.

11 Perkov, D., Primorac, D., Kozina, G.: Business negotiation as a crucial component of sales, Proceedings of the 13th International Scientific Conference on Economic and Social Development, Barcelona, 14-16 April, 2016, p. 638-647.

12 Križman Pavlović, D., Ružić, E.: Negotiation and sources of negotiation power: their role and importance in the exchange process in the corporate banking market, Economic research, 26(1) 2013, p. 115-138.

13 Brezak, S.: Vještine poslovnog pregovaranja s velikim trgovačkim lancima, MediAnali, 5(9) 2011, p. 151-178.

14 Small and medium-sized enterprises: an overview [https://ec.europa.eu/eurostat/web/ products-eurostat-news/-/EDN-20191125-1], accessed on 12/12/2019

15 The Small Business Development Promotion Act, (NN no. 29/02), Art. 3

16 Small and Medium Enterprises Report Croatia - 2019, Singer, S., Alpeza, M. (eds.), [https:// www.efse.lu/fileadmin/user_upload/File_Attachments/Studies/SME_REPORT_2019_EN_ WEB.pdf], accessed on 12/1/2020 
Therefore, the aim of this paper is twofold. On the one hand, we aim to examine if the managers of Croatian micro-enterprises perceive business negotiations as a source of competitive advantage. On the other hand, we aim to identify the underlying predictors of such perception. The paper is organized as follows. After the introduction, the second section brings insights into the negotiation context with special emphasis on the process of negotiation itself and other associated features in negotiation settings. The research methodology is outlined in the third section whereas the fourth section brings out the research results. Finally, in the last section, some conclusions have been drawn.

\section{INSIGHTS INTO THE NEGOTIATION SETTINGS}

Negotiation, as a fundamental human activity, has a variety of applications and is used in numerous and various contexts in everyday life. In the business context, negotiation skills are among the most essential skills in managing organizational challenges in today's highly competitive and rapidly changing environments. Additionally, negotiation is characterized as a frontline skill. ${ }^{17}$ Therefore, skillful negotiators are considered to be important assets that add to the firm's financial performance. ${ }^{18}$ In particular, global companies increasingly rely on the effectiveness of business negotiations for their survival and growth. ${ }^{19}$ In that sense, the special emphasis should be placed on the importance of negotiation training, i.e. development of the skills needed for successful negotiations. In that context, the development of employee negotiation skills in terms of various training programs and experience may help a negotiator develop the key competencies and lead to effective negotiation behaviors.

However, enhancing negotiation skills is a demanding, valuable, and often personally challenging task. ${ }^{20}$ In terms of the benefits of training employees in negotiation skills, it is claimed that developing negotiation skills makes a significant difference to the performance of all staff, both in internal and external negotiations. ${ }^{21}$ Similarly, it is argued that distributive, integrative, and adapt-

\footnotetext{
17 Jacks, A.: Negotiation - Smart Skills, London, 2011

18 ElShenawy, E.: Does negotiation training improve negotiators' performance?, Journal of European Industrial Training, 34(3) 2010, p. 192-210.

19 Reynolds, N., Simintiras, A., Vlachou. E.: International business negotiations: Present knowledge and direction for future research, International Marketing Review, 20(3) 2003, p. 236-261.

20 Ashcroft, S.: Commercial negotiation skills, Industrial and Commercial Training, 36(6) 2004, p. 229-233.

21 Gates, S.: Time to take negotiation seriously, Industrial and Commercial Training, 38(5) 2006, p. 238-241.
} 
able negotiation skills are developed most effectively via different learning and development activities. ${ }^{22}$ In that sense, an integrative approach in a cooperation agreement results in more favorable outcomes than competitive negotiation behavior. ${ }^{23}$ The role of negotiation experience is another factor worth examining. It is claimed that negotiation experience allows practice in various approaches and skills and that it reduces ambiguity for appropriate behavior. ${ }^{24}$ Besides, the experience was found to enhance and foster integrative performance. ${ }^{25}$

In business and organizational settings, cultural dimensions and contextual environments are of major importance and, therefore, should also be taken into consideration. It is common knowledge that different countries reflect different cultural environments within which negotiations take place. In that context, culture influences many aspects of negotiators' assumptions, strategies, and outcomes. ${ }^{26}$ It is often stressed that negotiating in a global environment benefits from a clear understanding of how negotiators' cultures influence their interests and the strategies they bring to the negotiation table. ${ }^{27}$ As regards the choice of negotiation strategies, culture-dependent preferences for negotiation strategies could lead to conflict when negotiations cross borders. ${ }^{28}$ On the other hand, being culturally literate allows negotiators to anticipate, interpret, and respect their counterpart's behavior. ${ }^{29}$

While negotiating, both counterparts and situations change. Further, change can trigger uncertainty in outcomes and the range of associated risks. Therefore, implementing changes in the negotiation process is one of the most important issues facing managers and affecting negotiation performance. People

22 Chapman, E., Miles, E., Maurer, T.: A proposed model for effective negotiation skill development, Journal of Management Development, 36(7) 2017, p. 940-958.

23 Canet-Giner, M., Saorin-Iborra, C. M.: The influence of gender role on negotiation development and outcome, Equal Opportunities International, 26(3) 2007, p. 209-231.

24 Keegin, M. M., Stuhlmacher, A. F., Cotton, A. S.: Embracing context in leadership theory: Lessons from negotiation research, in: Storberg-Walker, J., Haber-Curran, P. (eds.): Theorizing Women \& Leadership: New Insights \& Contributions from Multiple Perspectives, Charlotte, 2017, p. 95.

25 Moran, S., Ritov, I.: Experience in integrative negotiations: What needs to be learned?, Journal of Experimental Social Psychology, 43(1) 2007, p. 77-90.

26 Gunia B. C., Brett, J. M., Gelfand, M. J.: The science of culture and negotiation, Current Opinion in Psychology, 8, 2016, p. 78-83.

27 Brett, J. M., Culture and negotiation strategy, Journal of Business \& Industrial Marketing, 32(4) 2017, p. 587-590.

28 Dinkevych, E. et al:: Can outnumbered negotiators succeed? The case of intercultural business negotiations, International Business Review, 26(3) 2017, p. 592-603.

29 Brett, J., Mitchell, T.: Searching for trustworthiness: culture, trust and negotiating new business relationships, International Journal of Conflict Management, 31(1), 2019, p. 17-39. 
are usually more comfortable with predictable, familiar situations than the changes that they should adopt. ${ }^{30}$ Consequently, resistance to implement or accept change may result in a difficult negotiation. The ability of negotiators to cope effectively with uncertainty can increase their power and strengthen their position in the negotiation process. Effective managers will recognize when change is desirable or inevitable and will respond accordingly. ${ }^{31}$

As an integral part of communication in everyday life, conflict may arise due to many different situations and factors. As regards conflict sources, they may emerge from perceived individual differences, scarcity of resources, differences in values, attitudes, relationship disagreements, cultural background, and misinterpretations. ${ }^{32}$ However, in the negotiation context, it is emphasized that conflict can be viewed as an opportunity for change. ${ }^{33}$ Similarly, conflict is regarded as a drive for some kind of change in the status quo. ${ }^{34}$ Consequently, conflict resolution skills are vital in approaching conflicts in a rational way and achieving outcomes. Moreover, the development of these skills results in a rational approach to problem-solving and, more importantly, prevents the conflict from happening. Conflict is not an exception in organizations or during the negotiation process.

In order to create mutually beneficial agreements, it is crucial to show and maintain a certain degree of flexibility during the negotiation process. Although the art of negotiation can be learned and applied, the self-motivation for change and the ability to be flexible is crucial to achieving a desirable negotiation outcome. ${ }^{35}$ Understanding how the negotiating context affects behavior has been found to be crucial in order to anticipate the reactions and behavior of the counterpart and gain the most favorable agreement possible. ${ }^{36}$ Creativity is closely related to flexibility. It is essential to adopt an attitude of openness towards the unknown and unanticipated elements and to express a certain degree of curiosity. In light of this, the idea of presenting a change in negotia-

30 Acuff, F. L.: How to negotiate anything with anyone anywhere around the world, New York, 2008, p. 10.

31 Robinson, L.: Managing Public Sport and Leisure Services, London, 2004, p. 153.

32 Gamble, T. K., Gamble, M. W.: Interpersonal Communication: Building Connections Together, Thousand Oaks, 2013, p. 323.

33 Barsky, A.: Conflict Resolution for the Helping Professions, Oxford, 2014

34 Doherty, N., Guyler, M.: The Essential Guide to Workplace Mediation \& Conflict Resolution: Rebuilding Working Relationships, London, 2008, p. 48.

35 Gates, S.: The Negotiation Book: Your Definitive Guide to Successful Negotiating, West Sussex, 2015, p. 10.

36 Saorin-Iborra, C. M., Redondo-Cano, A., Revuelto-Taboada, L.: How BATNAs perception impacts JVs negotiations, Management Decision, 51(2) 2013, pp. 419-433. 
tion framework should be presented in such a manner that it evokes sufficient curiosity among members to explore it further. ${ }^{37}$ As deadlocks are an integral part of the negotiation process, a well-developed sense of creativity adds a different perspective to the negotiation. Furthermore, it helps negotiators cope with a deadlock effectively, and continue the negotiation towards an outcome. Likewise, it has been stressed that negotiators who are mindful of style and structure are in a better position to overcome resistance, avoid deadlock, and achieve better outcomes. ${ }^{38}$

Negotiation is generally perceived as one of the most time and energy-consuming activities. As one of the essential elements of negotiation, time can affect many aspects of negotiation including basic negotiation processes and outcomes, choice of tactics, and basic psychological processes of emotion, cognition, and motivation. ${ }^{39}$ Emotions are a challenging issue in the field of business negotiation. The role of emotions has been increasingly emphasized in the negotiation context. ${ }^{40}$ Negotiators should be aware of their ability to manage emotions while negotiating. In general, controlling emotions lead to using them to one's advantage. ${ }^{41}$ Furthermore, the examination of negotiation skills addresses also self-awareness, mood-management, and self-motivation, but also reliability and trustworthiness. Likewise, self-regulation provides a powerful toolbox to master the challenges that negotiators face at the bargaining table. ${ }^{42}$ In this context, empathy plays an important role. It is argued that trust is a necessary precondition for empathy, even in the weakest form of credibility. ${ }^{43}$ Negotiator's cultural awareness can facilitate trust-building between business negotiators as well as the overall process of trust development.

37 Nilakant, V., Ramnarayan, S.: Change Management: Altering Mindsets in a Global Context, New Delhi, 2006, p. 186.

38 Malhotra, D.: Negotiating the Impossible: How to Break Deadlocks and Resolve Ugly Conflicts (without Money Or Muscle), Oakland, 2016, p. 14.

39 Carnevale, P. J.: Strategic time in negotiation, Current Opinion in Psychology, 26, 2019, p. 106-112.

40 Butt, A. N., Choi, J. N.: Does power matter?: Negotiator status as a moderator of the relationship between negotiator emotion and behavior, International Journal of Conflict Management, 21(2) 2010, p. 124-146.

${ }^{41}$ Carrell, M. R., Heavrin, C.: The Everyday Negotiator: 50 Practical Negotiation Tactics for Work and Life, Amherst, 2004, p. 42.

42 Jäger, A., Loschelder, D. D., Friese M.: How self-regulation helps to master negotiation challenges: An overview, integration, and outlook, European Review of Social Psychology, 26(1) 2015, p. 203-246.

43 Martinovsky, B.: Discourse analysis of emotion in face-to-face group decision and negotiation, in: Martinovsky, B. (ed.), Emotion in Group Decision and Negotiation, Dordrecht, 2015, p. 181. 
Improved understanding of different dimensions shaping negotiation context helps a negotiator to better assess the counterpart's behavior, to select appropriate strategies and techniques, and to achieve more favorable outcomes.

\section{METHODOLOGY}

For the purpose of this paper, an empirical survey was conducted on a random sample of managers in Croatian companies from March to June 2017. Before conducting the main survey, a preliminary survey was carried out to assure that all questions and measurements were correctly structured. As the aim of this paper is to determine the existence of the relationship between dependent variable competitive advantage and suggested predictors, the proposed model consists of four variables (Table 1).

Table 1. Variables and measurements

\begin{tabular}{|l|l|}
\hline Variables & Measurements \\
\hline Competitive advantage & $\begin{array}{l}\text { Not source of competitive advantage } \\
\text { Neutral } \\
\text { Source of competitive advantage }\end{array}$ \\
\hline Negotiating frequency & $\begin{array}{l}\text { Never/rarely } \\
\text { Occasionally } \\
\text { Regularly }\end{array}$ \\
\hline $\begin{array}{l}\text { Negotiation skills } \\
\text { development }\end{array}$ & $\begin{array}{l}\text { Unimportant } \\
\text { Important for my job } \\
\text { Important for all employees }\end{array}$ \\
\hline \multirow{2}{*}{ Willingness to change } & $\begin{array}{l}\text { Complete unwillingness to change } \\
\text { Only risk-free changes } \\
\text { Gradual adaptation to a new situation } \\
\text { Complete willingness to change }\end{array}$ \\
\hline
\end{tabular}

Source: Authors' analysis

Competitive advantage is a dependent variable. It is measured as a managers' opinion on whether business negotiation is a source of competitive advantage giving three choices: negative, neutral, and affirmative. The remaining three variables are independent ones. The variable negotiating frequency indicates the experience of a negotiator, i.e. whether the negotiation is a routine or an- 
cillary activity. For this purpose, the respondents were asked to select one of the following answers: never or rarely, occasionally or regularly. The second independent variable is negotiation skills development. The measurement for this variable was a statement about the importance of acquiring new knowledge via a three-point scale: unimportant, important for my job, and important for all employees. Finally, the willingness to change is the independent variable measured using the four-point scale including complete unwillingness to change, accepting only risk-free changes, performing changes only if necessary, and completes willingness to change. The sample consisted of the companies listed in the Croatian Chamber of Commerce register. The questionnaires were sent to the managers via e-mail. Out of the total amount of 550 questionnaires sent, 132 valid questionnaires were received, giving the return rate of $24 \%$.

\section{RESULTS}

The data gathered from the questionnaires were analyzed through the Statistical Package for the Social Sciences (SPSS) version 20.0. Table 2 shows descriptive statistics of the variables. The minimum, maximum, mean, and standard deviations have been calculated.

Table 2. Descriptive statistics

\begin{tabular}{|c|c|c|c|c|c|}
\hline Variables & $\mathbf{N}$ & Minimum & Maximum & Mean & Std. Deviation \\
\hline Competitive advantage & 132 & 1.0 & 3.0 & 2.705 & 0.5204 \\
\hline Negotiating frequency & 132 & 1.0 & 3.0 & 2.621 & 0.5599 \\
\hline $\begin{array}{c}\text { Negotiation skills } \\
\text { development }\end{array}$ & 132 & 1.0 & 3.0 & 2.242 & 0.7426 \\
\hline Willingness to change & 132 & 1.0 & 4.0 & 3.114 & 0.8529 \\
\hline
\end{tabular}

Source: Authors' analysis

Table 3 indicates the sample frequencies. Almost three-quarters of respondents $(73.5 \%)$ considered business negotiation as a source of competitive advantage. Little less than a quarter of them did not have a clear opinion on the importance of business negotiation in a competitive sense. Additionally, a negligible number of respondents did not give any strategic importance to business negotiation. 
Table 3. Sample frequencies

\begin{tabular}{|l|c|c|}
\hline Variable & Frequency & Percent \\
\hline Competitive advantage & $\mathbf{1 3 2}$ & $\mathbf{1 0 0}$ \\
Not source of competitive advantage & 4 & 3 \\
Neutral & 31 & 23.5 \\
Source of competitive advantage & 97 & 73.5 \\
\hline Negotiating frequency & $\mathbf{1 3 2}$ & $\mathbf{1 0 0}$ \\
Never/rarely & 5 & 3.8 \\
Occasionally & 40 & 30.3 \\
Regularly & 87 & 65.9 \\
\hline Negotiation skills development & $\mathbf{1 3 2}$ & $\mathbf{1 0 0}$ \\
Unimportant & 24 & 18.2 \\
Important for my job & 52 & 39.4 \\
Important for all employees & 56 & 42.4 \\
\hline Willingness to change & $\mathbf{1 3 2}$ & $\mathbf{1 0 0}$ \\
Complete unwillingness to change & 4 & 3 \\
Only risk-free changes & 29 & 22 \\
Gradual adaptation to a new situation & 47 & 35.6 \\
Complete willingness to change & 52 & 39.4 \\
\hline
\end{tabular}

Source: Authors' analysis

As can be seen in Table 3, the majority of managers $(65.9 \%)$ negotiate on a regular basis. However, it is well known that in micro-enterprises every person employed, even an owner or manager, performs multiple tasks in daily business operations. Approximately the same number of managers admitted that negotiation skills development was crucial for themselves or for all employees in achieving successful outcomes in the negotiation process. Almost $40 \%$ of respondents were completely willing to change. About a third of them gradually adapted to a new situation, whereas $22 \%$ opted for risk-free changes.

Before proceeding to a more complex analysis, the correlation between the dependent variable and independent variables was evaluated (Table 4). 
Table 4. Correlation matrix

\begin{tabular}{|l|c|c|c|c|}
\hline & $\begin{array}{c}\text { Competitive } \\
\text { advantage }\end{array}$ & $\begin{array}{c}\text { Negotiating } \\
\text { frequency }\end{array}$ & $\begin{array}{c}\text { Negotiation } \\
\text { skills } \\
\text { development }\end{array}$ & $\begin{array}{c}\text { Willingness to } \\
\text { change }\end{array}$ \\
\hline $\begin{array}{l}\text { Competitive } \\
\text { advantage }\end{array}$ & 1 & $0,268^{* *}$ & $0.266^{* *}$ & $0.265^{* *}$ \\
\hline $\begin{array}{l}\text { Negotiating } \\
\text { frequency }\end{array}$ & $0,268^{* *}$ & 1 & 0,131 & 0,171 \\
\hline $\begin{array}{l}\text { Negotiation } \\
\text { skills } \\
\text { development }\end{array}$ & $0.266^{* *}$ & 0,131 & 1 & $0,221^{*}$ \\
\hline $\begin{array}{l}\text { Willingness } \\
\text { to change }\end{array}$ & $0.265^{* *}$ & 0,171 & $0,221^{*}$ & 1 \\
\hline
\end{tabular}

** Correlation is significant at the 0.01 level (2-tailed).

* Correlation is significant at the 0.05 level (2-tailed).

Source: Authors' analysis

The results from Table 4 reveal that there is a statistically significant positive correlation between predictors and the dependent variable. Respondents who negotiate more frequently are more aware of the importance of negotiation for achieving the competitive advantage of their enterprises. Putting efforts on investing in negotiation skills development and acquiring new knowledge are going along with the awareness of the strategic importance of business negotiation as a source of competitive advantage. Additionally, the results have proved that competitive advantage depends on the ability to adapt to the ever-changing business environment.

The next step in the analysis is multiple linear regression in order to evaluate the effect of three predictors (negotiating frequency, negotiation skills development, and willingness to change) and competitive advantage as the dependent variable. The equation of multiple linear regression for this particular model looks as follows:

$$
Y_{3}=\beta_{0}+\beta_{1} X_{1+} \beta_{2} X_{2}+\beta_{3} X_{3}
$$


where are:

$\mathrm{Y}_{3}=$ competitive advantage value,

$\mathrm{X}_{1}=$ negotiating frequency observation,

$\mathrm{X}_{2}=$ negotiation skills development observation

$\mathrm{X}_{3}=$ willingness to change observation

According to Table 5, these three predictors (negotiating frequency, negotiation skills development and willingness to change) explain $15.8 \%$ of the dependent variable.

Table 5. Multiple linear regression summary

\begin{tabular}{|c|c|c|c|}
\hline $\mathbf{R}$ & $\mathbf{R}^{\mathbf{2}}$ & F change & Sig. F change \\
\hline 0.398 & 0.158 & 8.013 & 0.000 \\
\hline
\end{tabular}

Source: Authors' analysis

The results of multiple linear regression models are given in Table 6. From these results, the competitive advantage value for each item may be predicted as follows:

$$
Y_{5}=1.529+0.196 * X_{1}+0.138 * X_{2}+0.113 * X_{3}
$$

Table 6. Multiple linear regression model

\begin{tabular}{|c|c|c|c|c|c|}
\hline & \multicolumn{2}{|c|}{$\begin{array}{c}\text { Unstandardized } \\
\text { Coefficients }\end{array}$} & \multirow{2}{*}{$\begin{array}{c}\text { Standardized } \\
\text { Coefficients }\end{array}$} & \multirow[b]{2}{*}{$\mathbf{t}$} & \multirow[b]{2}{*}{ Sig. } \\
\hline & B & Std. Error & & & \\
\hline Constant & 1.529 & 0.249 & & 6.140 & 0.000 \\
\hline Negotiating frequency & 0.196 & 0.077 & 0.210 & 2.545 & 0.012 \\
\hline $\begin{array}{l}\text { Negotiation skills } \\
\text { development }\end{array}$ & 0.138 & 0.059 & 0.197 & 2.359 & 0.020 \\
\hline Willingness to change & 0.113 & 0.051 & 0.186 & 2.210 & 0.029 \\
\hline
\end{tabular}

Source: Authors' analysis 
It can be observed from Table 6 that all three predictors have a positive influence on the dependend variable. These results are in line with the correlation analysis shown in Table 4. The third step in statistical analysis is the evaluation of the relative contribution of each predictor to the competitive advantage variable (Table 7).

Table 7. Hierarchical regression summary

\begin{tabular}{|l|c|c|c|}
\hline & M1 & M2 & M3 \\
\hline $\mathbf{R}$ & 0.268 & 0.355 & 0.398 \\
\hline $\mathbf{R}^{\mathbf{2}}$ & 0.072 & 0.126 & 0.158 \\
\hline $\mathbf{R}^{2}$ change & 0.072 & 0.054 & 0.032 \\
\hline F change & 10.057 & 9.296 & 8.013 \\
\hline Sig. F change & 0.002 & 0.000 & 0.000 \\
\hline
\end{tabular}

Source: Authors' analysis

Each predictor is added to the following order: M1 negotiating frequency, M2 negotiation skills development, and M3 willingness to change. Negotiating frequency has the highest relative contribution and makes it $7.2 \%$. The second highest contribution refers to predictor negotiation skills development (5.4\%) whereas the third is a willingness to change with the contribution of $3.2 \%$.

\section{CONCLUSION}

In business settings, an enhanced understanding of negotiation context can facilitate all stages of the negotiation process, smooth the path towards better negotiation performance, and lead to successful negotiation in the future. Consequently, all businesses should consider investing in negotiation skills development. In particular, it is crucial for micro-enterprises. Some of these enterprises are at the beginning of their life cycle. It is common knowledge that the first few years are considered to be the most critical period for new companies as the rate of failure is rather high. In that sense, entrepreneurs or managers strive to achieve some sort of competitive advantage at the very beginning of the company's existence. The primary aim of this research was to investigate whether the managers of micro-enterprises see business negotiations as a source of competitive advantage. The research results reveal that negotiating frequency, negotiation skills development, and willingness to change 
influence the opinion that the business negotiations are a source of competitive advantage.

Apart from the variables examined in the paper, areas for future research should be outlined. To satisfy the needs of future research, the sample should be extended and include both small and medium-sized enterprises. That way, it would be possible to identify differences between micro-enterprises and other SMEs in the negotiation context. Furthermore, future research should concentrate on the company's market position, industry competition, or geographical location. These variables have not been taken into account in the paper. Moreover, it would be interesting to examine additional negotiators' attributes, such as assertiveness, cooperativeness, trust, and creativity. As mentioned previously, the literature offers a limited understanding of negotiating behavior of Croatian managers. Therefore, the paper contributes to the existing literature by providing new insights into the negotiating behavior of micro-entrepreneurs in Croatia. Also, this research could serve as a basis for conducting future studies on this topic, particularly in the Croatian negotiation context.

\section{LITERATURE}

1. Acuff, F. L.: How to negotiate anything with anyone anywhere around the world, New York, 2008

2. Age, L. J., Eklinder-Frick, J.: Goal-oriented balancing: happy-happy negotiations beyond win-win situations, Journal of Business \& Industrial Marketing, 32(4) 2017, pp. 525-534.

- DOI: https://doi.org/10.1108/JBIM-12-2015-0237

3. Ashcroft, S.: Commercial negotiation skills, Industrial and Commercial Training, 36(6) 2004, p. 229-233.

- DOI: https://doi.org/10.1108/00197850410556658

4. Barsky, A.: Conflict Resolution for the Helping Professions, Oxford, 2014

5. Brett J., Thompson L.: Negotiation, Organizational Behavior and Human Decision Processes, 136, 2016, p. 68-79.

- DOI: https://doi.org/10.1016/j.obhdp.2016.06.003

6. Brett, J. M., Culture and negotiation strategy, Journal of Business \& Industrial Marketing, 32(4) 2017, p. 587-590.

- DOI: https://doi.org/10.1108/JBIM-11-2015-0230

7. Brett, J., Mitchell, T.: Searching for trustworthiness: culture, trust and negotiating new business relationships, International Journal of Conflict Management, 31(1) 2019, p. 17-39.

- DOI: https://doi.org/10.1108/IJCMA-05-2019-0085 
8. Butt, A. N., Choi, J. N.: Does power matter?: Negotiator status as a moderator of the relationship between negotiator emotion and behavior, International Journal of Conflict Management, 21(2) 2010, p. 124-146.

- DOI: https://doi.org/10.1108/10444061011037378

9. Brezak, S.: Vještine poslovnog pregovaranja s velikim trgovačkim lancima, MediAnali, 5(9) 2011, p. 151-178.

10. Canet-Giner, M., Saorin-Iborra, C. M.: The influence of gender role on negotiation development and outcome, Equal Opportunities International, 26(3) 2007, p. 209-231.

- DOI: https://doi.org/10.1108/02610150710735499

11. Carnevale, P. J.: Strategic time in negotiation, Current Opinion in Psychology, 26, 2019, p. 106-112.

- DOI: https://doi.org/10.1016/j.copsyc.2018.12.017

12. Carrell, M. R., Heavrin, C.: The Everyday Negotiator: 50 Practical Negotiation Tactics for Work and Life, Amherst, 2004

13. Chapman, E., Miles, E., Maurer, T.: A proposed model for effective negotiation skill development, Journal of Management Development, 36(7) 2017, p. 940-958.

- DOI: https://doi.org/10.1108/JMD-01-2016-0002

14. Dinkevych, E., Wilken, R., Aykac, T., Jacob, F., Prime, N.: Can outnumbered negotiators succeed? The case of intercultural business negotiations, International Business Review, 26(3) 2017, p. 592-603.

- DOI: https://doi.org/10.1016/j.ibusrev.2016.12.001

15. Doherty, N., Guyler, M.: The Essential Guide to Workplace Mediation \& Conflict Resolution: Rebuilding Working Relationships, London, 2008

16. ElShenawy, E.: Does negotiation training improve negotiators' performance?, Journal of European Industrial Training, 34(3) 2010, p. 192-210.

- DOI: https://doi.org/10.1108/03090591011031719

17. Gamble, T. K., Gamble, M. W.: Interpersonal Communication: Building Connections Together, Thousand Oaks, 2013.

- DOI: https://doi.org/10.4324/9781315699721

18. Gates, S.: Time to take negotiation seriously, Industrial and Commercial Training, 38(5) 2006, p. 238-241.

- DOI: https://doi.org/10.1108/00197850610677689

19. Gates, S.: The Negotiation Book: Your Definitive Guide to Successful Negotiating, West Sussex, 2016

20. Gunia B. C., Brett, J. M., Gelfand, M. J.: The science of culture and negotiation, Current Opinion in Psychology, 8, 2016, p. 78-83.

- DOI: https://doi.org/10.1016/j.copsyc.2015.10.008

21. Jacks, A.: Negotiation - Smart Skills, London, 2011 
22. Jäger, A., Loschelder, D. D., Friese M.: How self-regulation helps to master negotiation challenges: An overview, integration, and outlook, European Review of Social Psychology, 26(1) 2015, p. 203-246.

- DOI: https://doi.org/10.1080/10463283.2015.1112640

23. Keegin, M. M., Stuhlmacher, A. F., Cotton, A. S.: Embracing context in leadership theory: Lessons from negotiation research, in: Storberg-Walker, J., Haber-Curran, P. (eds.): Theorizing Women \& Leadership: New Insights \& Contributions from Multiple Perspectives, Charlotte, 2017, p. 89-102.

24. Križman Pavlović, D., Kalanj, I.: Role of business negotiation in gaining competitive advantage, Economic Research, 21(4) 2008, p. 62-81.

25. Križman Pavlović, D., Ružić, E.: Negotiation and sources of negotiation power: their role and importance in the exchange process in the corporate banking market, Economic research, 26(1) 2013, p. 115-138.

- DOI: https://doi.org/10.1080/1331677X.2013.11517593

26. Magee J.: The Managerial Leadership Bible: Learning the Strategic, Organizational, and Tactical Skills Everyone Needs Today, New Jersey, 2015

27. Malhotra, D.: Negotiating the Impossible: How to Break Deadlocks and Resolve Ugly Conflicts (without Money or Muscle), Oakland, 2016

28. Martinovsky, B.: Discourse analysis of emotion in face-to-face group decision and negotiation, in: Martinovsky, B. (ed.), Emotion in Group Decision and Negotiation, Dordrecht, 2015, p. 137-188.

- DOI: https://doi.org/10.1007/978-94-017-9963-8

29. Moran, S., Ritov, I.: Experience in integrative negotiations: What needs to be learned?, Journal of Experimental Social Psychology, 43(1) 2007, p. 77-90.

- DOI: https://doi.org/10.1016/j.jesp.2006.01.003

30. Nilakant, V., Ramnarayan, S.: Change Management: Altering Mindsets in a Global Context, New Delhi, 2006

31. Perkov, D., Primorac, D., Kozina, G.: Business negotiation as a crucial component of sales, Proceedings of the 13th International Scientific Conference on Economic and Social Development, Barcelona, 14-16 April, 2016, p. 638-647.

32. Reynolds, N., Simintiras, A., Vlachou. E.: International business negotiations: Present knowledge and direction for future research, International Marketing Review, 20(3) 2003, p. 236-261.

- DOI: https://doi.org/10.1108/02651330310477585

33. Robinson, L.: Managing Public Sport and Leisure Services, London, 2004.

- DOI: https://doi.org/10.4324/9780203646557

34. Saorin-Iborra, C. M., Redondo-Cano, A., Revuelto-Taboada, L.: How BATNAs perception impacts JVs negotiations, Management Decision, 51(2) 2013, p. 419433.

- DOI: https://doi.org/10.1108/00251741311301894 
35. Small and medium-sized enterprises: an overview [https://ec.europa.eu/eurostat/ web/products-eurostat-news/-/EDN-20191125-1], accessed on 12/12/2019

36. Small and Medium Enterprises Report Croatia - 2019, Singer, S., Alpeza, M. (eds.), [https://www.efse.lu/fileadmin/user_upload/File_Attachments/Studies/ SME_REPORT_2019_EN_WEB.pdf], accessed on 12/1/2020

37. Spencer, P. J.: Successful Negotiation Skills, West Midlands, 2013

38. Šlogar, H., Cigan, V.: Umijeće pregovaranja kao ključna kompetencija u razvoju poduzetništva, Učenje za poduzetništvo, 2(2) 2012, p. 259-265.

39. The Small Business Development Promotion Act, (NN no. 29/02), Art. 3

40. Tomašević Lišanin, M.: Pregovaranje - poslovni proces koji dodaje vrijednost, Zbornik Ekonomskog fakulteta u Zagrebu, 2(1) 2004, p. 143-158.

41. Tomašević Lišanin, M., Razum, A., Marić, N.: Skills and negotiation behaviour of Croatian Businessmen, International Journal of Sales, Retailing and Marketing, 4(4) 2015, p. 168-178.

42. Uher, T. E., Loosemore, M.: Essentials of Construction Project Management, Sydney, 2004. 
